\title{
Comparison of Some Relative Gene Expressions in the Yolk Sac Membrane and Small Intestine of the Embryos in the Layer Hybrid and Pure Breeds
}

\section{-Author(s)}

\section{Onbaşilar EE' \\ Erdoğan $\mathrm{M}^{\prime \prime}$ \\ Erol S'II \\ Kahraman M \\ Güngör ÖF'}

Department of Animal Breeding and Husbandry, Faculty of Veterinary Medicine, Ankara University, Ankara, Turkey.

" Department of Medical Biology and Genetics, Faculty of Veterinary Medicine, Afyon Kocatepe University, Afyonkarahisar, Turkey.

III Food Control Laboratory Directorate, Republic of Turkey Ministry of Food Agriculture and Livestock, Istanbul, Turkey.

\section{nail Address}

Corresponding author e-mail address Esin Ebru Onbaşılar

Department of Animal Breeding and Husbandry, Faculty of Veterinary Medicine, University of Ankara, 06110, Turkey. Phone: +90-312-3170315

Email: onbasilar@ankara.edu.tr

\section{EKeywords}

Embryo, gene expression, layer hybrid, pure breed.

\section{ABSTRACT}

Pure breeds are important due to the fact that they adapt well to poor husbandry conditions. However, gene expression of digestive enzymes and nutrient transporters of pure breeds and layer hybrids have not been studied yet. Therefore, this study was directed to detect the gene expression of digestive enzymes and nutrient transporters in the yolk sac membrane and small intestine of the embryos in layer hybrid and pure breeds. A total of 354 hatching eggs were collected from 29 wk old Denizli, Gerze and Lohman White (LW) breeder flocks. Twelve eggs from each genotype were selected at embryonic day 19 (E19) and day 21 (E21). APN, SI, PepT1, EAAT3, CAT1, BAT, SGLT1 and GLUT5 mRNA expressions were evaluated in the yolk sac membrane (YSM) and small intestine of the embryos from different genotypes. Expressions of APN and EAAT3 in the small intestine of Denizli embryo were upregulated from E19 to E21. B ${ }^{0}$ AT, PepT1 and SGLT1 expressions were upregulated in the small intestine of pure breed and layer hybrid embryos with increasing embryonic age. SI expression in the small intestine of the LW embryos was upregulated from E19 to E21. APN, B ${ }^{0}$ TT and EAAT3 expressions in the YSM of Denizli embryos were dowregulated from E19 to E21. EAAT3 and SGLT1 expressions in the YSM of Gerze embryos were upregulated at E21 and compared to E19. Taken together, our results indicate that genotype and embryonic age influenced the expression of digestive enzymes and nutrient transporter genes in the small intestine and YSM of embryos.

\section{INTRODUCTION}

The embryonic development is important for posthatch growth. This is influenced by breeder age, egg storage and incubation (Chen et al., 2016). Yolk sac provides the developing embryo with the nutrients required for growth and energy (Noble \& Cocchi, 1990). During incubation, yolk nutrients are transported to the embryo via the endothelial cells of the yolk sac membrane (YSM). The nutrients pass from the yolk sac (YS) content to the YSM by receptor-mediated endocytosis of lipoproteins (Hermann et al., 2000) and minerals (Yadgary et al., 2010). Nutrients are then delivered into the blood vessels that protrude into the YSM and transported to the embryonic tissues (Yadgary \& Uni, 2012). Nutrient transporters are responsible for nutrient absorption; so the expression of these nutrients transporters can influence overall nutrient status as well as the growth and development of embryos (Mott et al., 2008; Shinde et al., 2015; Speier et al., 2012). Aminopeptidase N (APN) and sucrose Isomaltase (SI) are digestive enzymes. PepT1, EAAT3, $\mathrm{B}^{\circ} \mathrm{AT}$, CAT1, SGLT1 and GLUT5 are important for transporting related nutrients (Spier et al., 2012, Yadgary et al., 2011). 
Animal biodiversity has become an important issue because of the changes in the production systems (Zanetti et al., 2010). The well-being of poultry and their rearing conditions are important (Rızzı \& Chiericato, 2010). Pure breeds are preferred because of this idea and changed the rearing system (Rızzı \& Chiericato, 2005). Pure breeds seem to have the advantage of being well adapted to the local stressful conditions in the rural areas such as high temperature, serious disease problems, poor farming hygiene and unbalanced diets (Bessadok et al., 2003, Fotsa et al., 2007, Kingori et al., 2010). Denizli and Gerze are Turkish native chicken breeds which lay eggs with white color shells. Lohman White is a commonly used layer hybrid which also lays eggs with white color shells. Denizli and Gerze are reared primarily for egg and they have low egg production, whereas Lohman White is a hybrid for selection for high egg production. Knowledge including gene expression of purebreds and hybrids in embryonic period is lacking. Therefore, the objective of this study was to explore the developmental expression profiles of the APN, SI, PepT1, EAAT3, CAT1, B ${ }^{\circ}$ AT, SGLT1 and GLUT5 in YSM and small intestine of embryos from different white layer genotypes during incubation.

\section{MATERIALS AND METHODS}

This study was approved by Ankara University Animal Care and Use Committee (2015/5/101). A total of 354 hatching eggs from 2 different pure breeds (Denizli and Gerze) and one layer hybrid (Lohman White) were used. Denizli and Gerze are Turkish pure breeds. Therefore, we used in this study 3 different genotypes. Flocks were at the same age ( 29 wk of age).

Eggs from each genotype were incubated in the same incubator (Çimuka Incubator, Ankara, Turkey) at $37.7^{\circ} \mathrm{C}, 53 \%$ relative humidity $(\mathrm{RH})$ and were turned till $18 \mathrm{~d}$ of incubation. On day 18, all eggs were transferred to the hatcher (Çimuka Incubator, Ankara, Turkey) at $37.5^{\circ} \mathrm{C}$ and $70 \% \mathrm{RH}$ until day 21 of the incubation. Twelve eggs from each genotype were selected at the beginning of the embryonic day 19 (E19) and E21 of incubation. The eggs were opened and the embryos were sacrificed by cervical dislocation and subsequently the YS and small intestines were dissected from each embryo and cleaned with PBS. Then the YSM and small intestine were flash frozen within cryogenic tubes separately in liquid nitrogen and stored at $-80^{\circ} \mathrm{C}$. The RNA was extracted from the yolk sac membrane and small intestine samples using the the commercial kit (Gene Jet, Thermo K0732) according to the manufacturer's instructions. The concentration and purity of the RNA were determined by Multiskan Go (Thermo Scientific) and also Qubit RNA HS Assay kit (Thermo Fisher, Q 32855) with Qubit 2.0 Florometre (Invitrogen). cDNA was synthesized from 1 $\mu \mathrm{g}$ total RNA using the Maxima First Strand CDNA kit (Thermo Scientific, K1672). To accurately determine the efficiency of PCR reactions, a 4-log dilution series was performed and then the synthesized CDNAs were diluted 1:30 before the addition to PCR reactions. GAPDH was used as a housekeeping gene. APN, $\mathrm{B}^{\circ} \mathrm{AT}$, EAAT3, CAT1, PepT1, SI, SGLT, GLUT5 and GAPDH gene specific primers were designed using FastPCR 6.1.2 program (Kalendar et al., 2009) (Table 1).

Real-time PCR was performed on LightCycler ${ }^{\circledR} 480$ II (Roche Applied Science) instrument. For each $25 \mu \mathrm{L}$ $P C R$ reaction, $2 \mu \mathrm{L}$ of the cDNA (diluted 1:30), $12.5 \mu \mathrm{L}$ of Maxima SYBR Green/ROX qPCR Master Mix (Thermo Scientific, K0223), $0.5 \mu \mathrm{L}$ of the forward and reverse primer $(5 \mu \mathrm{M})$ and $9.5 \mu \mathrm{L}$ of water were added. The reaction was incubated at $95^{\circ} \mathrm{C}$ for $10 \mathrm{~min}$ followed by repeated 40 cycles with $95^{\circ} \mathrm{C}$ for $30 \mathrm{~s}$ and $60^{\circ} \mathrm{C}$ for 1 min. All PCRs were performed in triplicate.

\section{Statistical analysis}

The Relative Expression Software Tool V2.0.13 (REST 2009) was used for statistical analysis of relative gene expression results (Pfaffl et al., 2002). Significant results are indicated by $p<0.05$.

Table 1 - Primers used for real-time PCR

\begin{tabular}{|c|c|c|c|c|c|}
\hline Gene & $\begin{array}{l}\text { Forward primer } \\
5^{\prime} \rightarrow 3^{\prime}\end{array}$ & $\begin{array}{l}\text { Reverse primer } \\
5^{\prime} \rightarrow 3^{\prime}\end{array}$ & Genbank No & $T_{m}$ & $\begin{array}{c}\text { CDNA } \\
\mathrm{bp}\end{array}$ \\
\hline APN & CCTACCTGCTGGCCTTCATCG & GCCGTGTTGTAGTGCCTCTCAA & NM_204861 & 60 & 172 \\
\hline SI & TGGCATACAGGTTCGACGCAA & TACTGGGATGGCAAGCGGGTA & XM_422811 & 60 & 114 \\
\hline PepT1 & TGGCTGTAAGCTCCATAAACG & GAGACACAAGGTTTGATCCCA & NM_204365 & 60 & 139 \\
\hline EAAT3 & TGGATTCCAGTGTTTCTGGGA & CCAGGTTTAATGGTCACAACC & XM_424930 & 60 & 112 \\
\hline CAT1 & GTTATGTGACTGTTGGCGAGC & ATTTCATCGAACGTGGCGCTC & XM_417116 & 60 & 115 \\
\hline $\mathrm{B}^{0} \mathrm{AT}$ & TGTAGAAGGTGTGCTTGTACC & AGTAATTGCCAGACCTCAGGA & XM_419056 & 60 & 137 \\
\hline SGLT1 & TCTTTCTGGCTGGACGGAGCA & CCCACAAAATGTCCACTGCCA & XM_415247 & 60 & 85 \\
\hline GLUT5 & GGTGGGACCTCTGGTCAACAA & CCCCATGATAACACGGGAGACG & XM_417596 & 60 & 147 \\
\hline GAPDH & GGCCAAGGTCATCCATGACAA & TGCCATCTCTCCACAGCTTCC & NM_204305 & 60 & 119 \\
\hline
\end{tabular}




\section{RESULTS AND DISCUSSION}

APN is a digestive enzyme that converts proteins into amino acids and provides substrate for amino acid transporter such as B ${ }^{0}$ AT, CAT1 and EAAT3 (Drag et al., 2010, Kania et al., 1977). In the current study, expression of APN in the small intestine of Denizli embryo was upregulated from E19 to E21 (Table 2). The examined genotypes at E19, showed APN expression in the small intestine was 0.41 and 0.46 -fold lower and those at E21 was 0.46 and 0.37 -fold lower in Denizli and Gerze embryos compared to LW embryos, respectively (Table 3 and 4). This was downregulated in both Denizli and Gerze embryos compared to LW embryos in both at E19 and E21. This indicated that this gene is important in the small intestine of LW embryos both at E19 and E21 than in those of pure breeds. The examined expression of APN in the YSM, was downregulated with embryonic age in only Denizli

Table 2 - Relative expressions of some genes in the small intestine of different genotypes at E21 compared to E19.

\begin{tabular}{|c|c|c|c|c|}
\hline Gene & Group & $\begin{array}{l}\text { Relative } \\
\text { expression }\end{array}$ & $p$-value & Result \\
\hline \multirow{3}{*}{ APN } & $\begin{array}{l}\text { Lohman } \\
\text { White }\end{array}$ & $1.25 \pm 0.76$ & 0.220 & ND \\
\hline & Denizli & $1.40 \pm 0.68$ & 0.035 & UP \\
\hline & Gerze & $1.01 \pm 0.48$ & 0.935 & ND \\
\hline \multirow{3}{*}{$\mathrm{B}^{0} \mathrm{AT}$} & $\begin{array}{l}\text { Lohman } \\
\text { White }\end{array}$ & $3.90 \pm 0.43$ & 0.030 & UP \\
\hline & Denizli & $4.51 \pm 0.75$ & 0.001 & UP \\
\hline & Gerze & $5.74 \pm 1.57$ & $<0.001$ & UP \\
\hline \multirow{3}{*}{ CAT1 } & $\begin{array}{l}\text { Lohman } \\
\text { White }\end{array}$ & $1.41 \pm 0.76$ & 0.068 & ND \\
\hline & Denizli & $0.63 \pm 0.13$ & 0.129 & ND \\
\hline & Gerze & $0.75 \pm 0.11$ & 0.450 & ND \\
\hline \multirow{3}{*}{ EAAT3 } & $\begin{array}{l}\text { Lohman } \\
\text { White }\end{array}$ & $1.78 \pm 0.82$ & 0.025 & UP \\
\hline & Denizli & $2.08 \pm 0.79$ & $<0.001$ & UP \\
\hline & Gerze & $1.17 \pm 0.46$ & 0.493 & ND \\
\hline \multirow{3}{*}{ PepT1 } & $\begin{array}{l}\text { Lohman } \\
\text { White }\end{array}$ & $3.98 \pm 2.13$ & $<0.001$ & UP \\
\hline & Denizli & $2.05 \pm 0.63$ & 0.004 & UP \\
\hline & Gerze & $2.63 \pm 0.94$ & $<0.001$ & UP \\
\hline \multirow{3}{*}{ SI } & $\begin{array}{l}\text { Lohman } \\
\text { White }\end{array}$ & $1.94 \pm 1.05$ & 0.001 & UP \\
\hline & Denizli & $1.90 \pm 0.10$ & 0.175 & ND \\
\hline & Gerze & $1.29 \pm 0.09$ & 0.587 & ND \\
\hline \multirow{3}{*}{ SGLT1 } & $\begin{array}{l}\text { Lohman } \\
\text { White }\end{array}$ & $2.60 \pm 1.27$ & $<0.001$ & UP \\
\hline & Denizli & $2.49 \pm 0.99$ & $<0.001$ & UP \\
\hline & Gerze & $1.48 \pm 0.60$ & 0.045 & UP \\
\hline \multirow{3}{*}{ GLUT5 } & $\begin{array}{l}\text { Lohman } \\
\text { White }\end{array}$ & $1.23 \pm 0.72$ & 0.266 & ND \\
\hline & Denizli & $0.71 \pm 0.24$ & 0.147 & ND \\
\hline & Gerze & $1.38 \pm 0.61$ & 0.080 & ND \\
\hline
\end{tabular}

Means \pm SEM are reported. ND, Sample group is not different to control group; UP, Upregulated.
Table 3 - Relative expressions of some genes in the small intestine of Denizli and Gerze embryos compared to LW embryos at E19.

\begin{tabular}{lcccc}
\hline Gene & Group & $\begin{array}{c}\text { Relative } \\
\text { expression }\end{array}$ & P-value & Result \\
\hline APN & Denizli & $0,41 \pm 0.24$ & 0.001 & DOWN \\
& Gerze & $0,46 \pm 0.27$ & $<0.001$ & DOWN \\
\multirow{2}{*}{ B AT } & Denizli & $1.00 \pm 0.14$ & 1.000 & ND \\
& Gerze & $0.56 \pm 0.08$ & 0.253 & ND \\
CAT1 & Denizli & $0.72 \pm 0.41$ & 0.082 & ND \\
& Gerze & $0.72 \pm 0.47$ & 0.023 & DOWN \\
\multirow{2}{*}{ EAAT3 } & Denizli & $0.59 \pm 0.33$ & 0.003 & DOWN \\
& Gerze & $0.69 \pm 0.34$ & 0.066 & ND \\
PepT1 & Denizli & $0.96 \pm 0.43$ & 0.868 & ND \\
& Gerze & $0.96 \pm 0.32$ & 0.839 & ND \\
\multirow{2}{*}{ SI } & Denizli & $1.00 \pm 0.66$ & 0.972 & ND \\
& Gerze & $1.13 \pm 0.78$ & 0.285 & ND \\
\multirow{2}{*}{ SGLT1 } & Denizli & $0.80 \pm 0.47$ & 0.215 & ND \\
& Gerze & $1.04 \pm 0.63$ & 0.815 & ND \\
\multirow{2}{*}{ GLUT5 } & Denizli & $0.92 \pm 0.49$ & 0.620 & ND \\
& Gerze & $1.12 \pm 0.38$ & 0.485 & ND \\
\hline
\end{tabular}

Means \pm SEM are reported. ND, Sample group is not different from control group; DOWN, Downregulated.

Table 4 - Relative expressions of some genes in the small intestine of Denizli and Gerze embryos compared to LW embryos at E21.

\begin{tabular}{lcccc}
\hline Gene & Group & $\begin{array}{c}\text { Relative } \\
\text { expression }\end{array}$ & $p$-value & Result \\
\hline \multirow{2}{*}{ APN } & Denizli & $0.46 \pm 0.19$ & $<0.001$ & DOWN \\
& Gerze & $0.37 \pm 0.17$ & $<0.001$ & DOWN \\
\multirow{2}{*}{ B0AT } & Denizli & $1.16 \pm 0.28$ & 0.626 & ND \\
& Gerze & $0.82 \pm 0.16$ & 0.574 & ND \\
\multirow{2}{*}{ CAT1 } & Denizli & $0.32 \pm 0.07$ & 0.002 & DOWN \\
& Gerze & $0.38 \pm 0.08$ & 0.010 & DOWN \\
EAAT3 & Denizli & $0.69 \pm 0.21$ & 0.123 & ND \\
& Gerze & $0.44 \pm 0.14$ & 0.003 & DOWN \\
PepT1 & Denizli & $0.49 \pm 0.15$ & 0.006 & DOWN \\
& Gerze & $0.63 \pm 0.19$ & 0.096 & ND \\
\multirow{2}{*}{ SI } & Denizli & $0.98 \pm 0.09$ & 0.961 & ND \\
& Gerze & $0.76 \pm 0.06$ & 0.564 & ND \\
\multirow{2}{*}{ SGLT1 } & Denizli & $0.77 \pm 0.26$ & 0.252 & ND \\
& Gerze & $0.59 \pm 0.18$ & 0.045 & DOWN \\
\multirow{2}{*}{ GLUT5 } & Denizli & $0.53 \pm 0.16$ & 0.019 & DOWN \\
& Gerze & $1.25 \pm 0.44$ & 0.316 & ND \\
\hline
\end{tabular}

Means \pm SEM are reported. ND, Sample group is not different from control group; DOWN, Downregulated.

genotype (Table 5). This result indicates that the yolk contents were more quickly used up in Denizli embryos and APN activity diminished. Speier et al. (2012) also indicated that the highest level of APN occurred at E15 and then decreased in the YSM of Cobb and Leghorn embryos. APN expression level did not differ among genotypes at E19 or at E21.

Amino acid transporters such as $B^{0} A T$ mRNA expression in the small intestine increased from E19 
Table 5 - Relative expressions of some genes in the YSM of different genotypes at E21 compared to E19.

\begin{tabular}{lcccc}
\hline Gene & Group & $\begin{array}{c}\text { Relative } \\
\text { expression }\end{array}$ & p-value & Result \\
\hline \multirow{3}{*}{ APN } & Lohman White & $0.89 \pm 0.25$ & 0.839 & ND \\
& Denizli & $0.39 \pm 0.15$ & 0.027 & DOWN \\
& Gerze & $0.77 \pm 0.28$ & 0.500 & ND \\
BoAT & Lohman White & $1.26 \pm 0.32$ & 0.731 & ND \\
& Denizli & $0.30 \pm 0.10$ & 0.024 & DOWN \\
& Gerze & $9.45 \pm 0.19$ & 0.090 & ND \\
CAT1 & Lohman White & $3.24 \pm 1.40$ & 0.024 & UP \\
& Denizli & $3.18 \pm 0.37$ & 0.205 & ND \\
& Gerze & $1.89 \pm 0.53$ & 0.220 & ND \\
EAAT3 & Lohman White & $1.15 \pm 0.42$ & 0.708 & ND \\
& Denizli & $0.52 \pm 0.34$ & 0.008 & DOWN \\
& Gerze & $6.13 \pm 1.55$ & $<0.001$ & UP \\
PepT1 & Lohman White & $1.47 \pm 0.31$ & 0.647 & ND \\
& Denizli & $0.89 \pm 0.52$ & 0.613 & ND \\
& Gerze & $0.97 \pm 0.20$ & 0.950 & ND \\
\multirow{2}{*}{ SGLT1 } & Lohman White & $1.92 \pm 0.44$ & 0.399 & ND \\
& Denizli & $1.64 \pm 0.64$ & 0.360 & ND \\
& Gerze & $2.43 \pm 0.89$ & 0.040 & UP \\
& Lohman White & $2.40 \pm 1.03$ & 0.132 & ND \\
GLUT5 & Denizli & $0.96 \pm 0.42$ & 0.938 & ND \\
& Gerze & $1.30 \pm 0.57$ & 0.390 & ND \\
\hline
\end{tabular}

Means $\pm S E M$ are reported. ND, Sample group is not different from control group; UP, Upregulated; DOWN, Downregulated.

to E21 in all examined genotypes. Expression of $\mathrm{B}^{0} \mathrm{AT}$ gene in the small intestine is thought to be more important for all embryos examined at E21 than at E19. Similarly, Chen et al. (2015) reported that $B^{0} A T$ was more important during late embryogenesis, because its level increased 220-fold from E9 to hatch time in their study. CAT1 gene expression in the small intestine did not differ in all genotypes at E21 compared to E19. However, EAAT3 gene expression in the small intestine of LW and Denizli embryos increased from E19 to E21. B ${ }^{\circ}$ AT, EAAT3 and CAT1 genes are important in amino acid absorption (Chen et al., 2016). B BAT and EAAT3 are brush-border membrane proteins. $\mathrm{B}^{\circ} \mathrm{AT}$ transports the neutral amino acids into the intestinal enterocyte. However, CAT1 is a basolateral protein that transports cationic amino acid out of the intestinal enterocyte (Speier et al., 2012). EAAT3 has a high affinity for glutamate; glutamate as an oxidative fuel source, enters the various metabolic sequences in enterocytes, increasing the amount of energy needed for rapidly growing embryos (Chen et al., 2015). mRNA expression of EAAT3 increased from E19 to E21. Similar results were found by Gilbert et al. (2007) and Chen et al. (2015). However, Chen et al. (2015) indicated that CAT1 reached higher levels at E9 and E11, then decreased with embryonic age, because it plays an important role in the early stages of embryonic development. However, in the current study, CAT1 expression maintained similar levels at the end of incubation compared to E19. At E19, EAAT3 expression was downregulated in Denizli embryos and CAT1 expression was downregulated in Gerze embryos in the small intestine compared to LW embryos (Table 6). CAT1 was downregulated in both Denizli and Gerze embryos compared to LW embryos and EAAT3 expression was downregulated in Gerze embryos compared to LW embryos at E21 (Table 7). CAT1 expression in the YSM increased with embryonic age in LW embryos but EAAT3 increased only Gerze embryos with increasing embryonic age. B ${ }^{0} A T$ and EAAT3 expressions in the YSM of Denizli embryos were lower than those at E19. CAT1 expression in the YSM of Denizli embryos was 3.24-fold lower than that of LW embryos at E19. EAAT3 expression was 0.27-fold lower than that of LW embryos at E19. B ${ }^{0} A T$, CAT1 and EAAT3 expression levels did not differ between genotypes at E21.

Table 6 - Relative expressions of some genes in the YSM of Denizli and Gerze embryos compared to LW embryos at E19.

\begin{tabular}{lcccc}
\hline Gene & Group & $\begin{array}{c}\text { Relative } \\
\text { expression }\end{array}$ & p-value & Result \\
\hline \multirow{2}{*}{ APN } & Denizli & $0.89 \pm 0.25$ & 0.834 & ND \\
& Gerze & $1.03 \pm 0.50$ & 0.940 & ND \\
B ${ }^{0}$ AT & Denizli & $1.26 \pm 0.32$ & 0.736 & ND \\
& Gerze & $0.15 \pm 0.01$ & 0.158 & ND \\
CAT1 & Denizli & $3.24 \pm 1.40$ & 0.024 & UP \\
& Gerze & $0.74 \pm 0.34$ & 0.572 & ND \\
EAAT3 & Denizli & $1.15 \pm 0.42$ & 0.711 & ND \\
& Gerze & $0.27 \pm 0.09$ & 0.029 & DOWN \\
PepT1 & Denizli & $1.47 \pm 0.31$ & 0.630 & ND \\
& Gerze & $1.38 \pm 0.25$ & 0.753 & ND \\
SGLT1 & Denizli & $1.92 \pm 0.44$ & 0.396 & ND \\
& Gerze & $0.59 \pm 0.12$ & 0.575 & ND \\
GLUT5 & Denizli & $2.40 \pm 1.03$ & 0.125 & ND \\
& Gerze & $0.69 \pm 0.31$ & 0.610 & ND \\
\hline
\end{tabular}

Means \pm SEM are reported. ND, Sample group is not different from control group; UP, Upregulated; DOWN, Downregulated.

PepT1 is localized at the brush border membrane. Amino acids are introduced into the enterocyte as di or tri peptides via PepT1 (Chen et al., 2016; Leibach \& Ganapathy, 1996). PepT1 expression was regulated in the developmental stage during the embryonic growth and its mRNA level rose from E16 to hatch (Chen et al., 2005, Gilbert et al., 2007, Speier et al., 2012). PepT1 expression in the intestine was upregulated in all the examined embryos from E19 to E21. This may be linked to the importance of proteins for embryonic development with increasing embryonic age. However, its expression levels did not differ in the YSM between 
age groups. At E21, PepT1 expression in the small intestine was 0.49-fold, a decrease in the Denizli embryos compared to LW embryos.

Table 7 - Relative expressions of some genes in the YSM of Denizli and Gerze embryos compared to LW embryos at E21.

\begin{tabular}{lcccc}
\hline Gene & Group & $\begin{array}{c}\text { Relative } \\
\text { expression }\end{array}$ & p-value & Result \\
\hline \multirow{2}{*}{ APN } & Denizli & $0.60 \pm 0.22$ & 0.369 & ND \\
& Gerze & $0.88 \pm 0.25$ & 0.812 & ND \\
\multirow{2}{*}{ B0AT } & Denizli & $0.41 \pm 0.10$ & 0.165 & ND \\
& Gerze & $1.11 \pm 0.05$ & 0.891 & ND \\
\multirow{2}{*}{ CAT1 } & Denizli & $1.52 \pm 0.29$ & 0.615 & ND \\
& Gerze & $0.56 \pm 0.23$ & 0.224 & ND \\
\multirow{2}{*}{ EAAT3 } & Denizli & $0.50 \pm 0.27$ & 0.075 & ND \\
& Gerze & $1.46 \pm 0.61$ & 0.362 & ND \\
PepT1 & Denizli & $1.13 \pm 0.51$ & 0.722 & ND \\
& Gerze & $0.91 \pm 0.34$ & 0.835 & ND \\
\multirow{2}{*}{ SGLT1 } & Denizli & $0.60 \pm 0.15$ & 0.383 & ND \\
& Gerze & $0.74 \pm 0.37$ & 0.475 & ND \\
\multirow{2}{*}{ GLUT5 } & Denizli & $0.51 \pm 0.30$ & 0.051 & ND \\
& Gerze & $0.37 \pm 0.17$ & 0.012 & DOWN \\
\hline
\end{tabular}

Means \pm SEM are reported. ND, Sample group is not different from control group; DOWN, Downregulated.

$\mathrm{SI}$ is a digestive enzyme and carbohydrates are separated from monosaccharides by this enzyme. $\mathrm{SI}$ expression in the small intestine cells of the LW embryos was upregulated at E21 compared with E19. Fold increase of SI was 1.94 from E19 to E21 in the LW embryos. This may be due to LW embryos need of high energy in this incubation period. However, expression of $\mathrm{SI}$ gene in the YSM of examined genotypes was not detected. Speier et al. (2012) reported that expression of SI gene in the YSM of Cobb and Leghorn breeds was detected at a very low level throughout the incubation. This study indicated that $\mathrm{SI}$ in the YSM may not be crucial at E19 and E21 for the embryos. Yadgary et al. (2010) reported that carbohydrates can be found in the yolk contents and their levels increase from midincubation to E19 and decrease from E19 to E21. Onbaşilar et al. (2017) indicated that Denizli and Gerze embryos consumed yolk composition quickly to the beginning of the E21. Therefore, APN, EAAT3 and SI expressions of these pure breeds were lower than those of the layer hybrids at E21.

SGLT1 is a brush border membrane protein (Speier et al., 2012, Yadgary et al., 2011). The SGLT1 gene expression in the YSM and small intestine of all examined embryos was upregulated from E19 to E21. Upregulation of SGLT1 in all genotypes at E21 would enhance the uptake of glucose for the energy needed to hatch. However, it was upregulated from E19 to
E21 in the YSM of Gerze embryos. No significant difference in the small intestine was found between genotypes at E19. While at E21, SGLT expression was downregulated in the small intestine of Gerze embryos compared to that of LW embryos.

GLUT5 is a brush border membrane protein that transports fructose into intestinal enterocyte (Speier et al., 2012). Expression of GLUT5 was similar with that of SGLT1 and its expression in both small intestine and YSM were similar with E19 and E21. Increasing embryonic age, GLUT5 expression in the small intestine was 0.53-fold lower in Denizli embryos compared with LW embryos. While, at E21, GLUT5 expression in the YSM of Gerze embryos was 0.37 -fold lower than that of LW embryos. This result showed that glucose transporter is more important in the hybrid embryos than pure breed embryos in the last embryonic stage.

\section{CONCLUSION}

Expressions of $\mathrm{B}^{0} \mathrm{AT}$, PepT1 and SGLT1 were upregulated in the small intestine of pure breed and layer hybrid embryos with increasing embryonic age. EAAT3, SI and APN expressions were higher in the hybrid embryos due to the higher quantity of protein and energy needed than for pure breed embryos at E21. Genotype and embryonic age have a changing effect on expression of gene in the YSM and small intestine. APN, B ${ }^{0} A T$, EAAT3, CAT1, PepT1, SI, SGLT and GLUT5 didn't show similar expression sides in the YSM and small intestine of different layer genotypes.

\section{ACKNOWLEDGMENTS}

This study was supported by TÜBITAK Fund (Project No: 1150920).

\section{REFERENCES}

Bessadok A, Khochilef I, El-Gazzah M. Etat des ressources génétiques de la population locale du poulet en Tunisie. Tropicultura 2003;21:167-172.

Chen $\mathrm{H}$, Pan $\mathrm{Y}$, Wong EA, Webb KE. Dietary protein level and stage of development affect expression of an intestinal peptide transporter (cPepT1) in chickens. Journal of Nutrition 2005;135:193-198.

Chen MX, Li XG, Yan HC, Wang XQ, Gao CQ. Effect of egg weight on composition, embryonic growth, and expression of amino acid transporter genes in yolk sac membranes and small intestines of the domestic pigeon (Columba livia). Poultry Science 2016;95:1425-1432.

Chen MX, Li XG, Yang JX, Gao CQ, Wang B, Wang XQ, et al. Growth of embryo and gene expression of nutrient transporters in the small intestine of the domestic pigeon (Columba livia). Journal of Zheijang University Science B 2015;16:511-523. 
Drag M, Bogyo M, Ellman JA, Salvesen GS. Aminopeptidase fingerprints, an integrated approach for identification of good substrates and optimal inhibitors. The Journal of Biological Chemistry 2010;285:3310-3318.

Fotsa JC, Bordas A, Rognon X, Tixier-Boichard M, Poné Kamdem D, Manjeli Y. Caractérisation des élevages et des poules locales et comparaison en station de leurs performances à celles d'une souche commerciale de type label au Cameroun. Journal La Recherche Avicole 2007;7:414417.

Gilbert ER, Li H, Emmerson DA, Webb Jr KE, Wong EA. Developmental regulation of nutrient transporter and enzyme mRNA abundance in the small intestine of broilers. Poultry Science 2007;86:1739-1753.

Hermann M, Mahon MG, Lindstedt KA, Nimpf J, Schneider WJ. Lipoprotein receptors in extraembryonic tissues of the chicken. The Journal of Biological Chemistry 2000;275:16837-16844.

Kalendar R, Lee D, Schulman AH. FastPCR software for PCR primer and probe design and repeat search. G3: Genes, Genomes, Genetics 2009;3:1-14

Kania RK, Santiago NA, Gray GM. Intestinal surface amino-oligopeptidases. II. Substrate kinetics and topography of the active site. The Journal of Biological Chemistry 1977;252:4929-4934.

Kingori AM, Wachira AM, Tuitoek JK. Indigenous chicken production in Kenya: a review. International Journal of Poultry Science 2010;9:309316.

Leibach FH, Ganapathy V. Peptide transporters in the intestine and the kidney. Annual Review of Nutrition 1996;16:99-119.

Mott $C R$, Siegel PB, Webb Jr KE, Wong EA. Gene expression of nutrient transporters in the small intestine of chickens from lines divergently selected for high or low juvenile body weight. Poultry Science 2008;87:2215-2224.

Noble RC, Cocchi M. Lipid metabolism and the neonatal chicken. Progress in Lipid Research 1990;29:107-140.

Onbaşilar EE, Kahraman M, Ahlat O, Güngör ÖF, Çalik A, Taban S, et al. Differences in egg nutrient availability and embryo development in white layer breeder genotypes. Poultry Science 2017;96:3600-3607.
Pfaffl MW, Horgan GW, Dempfle L. Relative expression software tool (RESTC) for group-wise comparison and statistical analysis of relative expression results in real-time PCR. Nucleic Acids Research 2002;30:e36.

Rizzi C, Chiericato GM. Organic farming production. Effect of age on the productive yield and egg quality of hens of two commercial hybrid lines and two local breeds. Italian Journal of Animal Science 2005;4:160162.

Rizzi C, Chiericato GM. Chemical composition of meat and egg yolk of hybrid and Italian breed hens reared using an organic production system. Poultry Science 2010;89:1239-1251.

Shinde AS, Goel A, Mehra M, Rokade J, Bhadauria P, Mandal AB, et al. Delayed post hatch feeding affects performance, intestinal morphology and expression pattern of nutrient transporter genes in egg type chickens. Journal of Nutrition and Food Sciences 2015:5:1-11.

Speier JS, Yadgary L, Uni Z, Wong EA. Gene expression of nutrient transporters and digestive enzymes in the yolk sac membrane and small intestine of the developing embryonic chick. Poultry Science 2012;91:1941-1949.

Yadgary L, Uni Z. Yolk sac carbohydrate levels and gene expression of key gluconeogenic and glycogenic enzymes during chick embryonic development. Poultry Science 2012;91:444-453.

Yadgary L, Cahaner A, Kedar O, Uni Z. Yolk sac nutrient composition and fat uptake in late-term embryos in eggs from young and old broiler breeder hens. Poultry Science 2010;89:2441-2452.

Yadgary L, Yair R, Uni Z. The chick embryo yolk sac membrane expresses nutrient transporter and digestive enzyme genes. Poultry Science 2011;90:410-416

Zanetti E, De-Marchi M, Dalvit C, Cassandro M. Genetic characterization of local Italian breeds of chickens undergoing in situ conservation. Poultry Science 2010;89:420-427. 